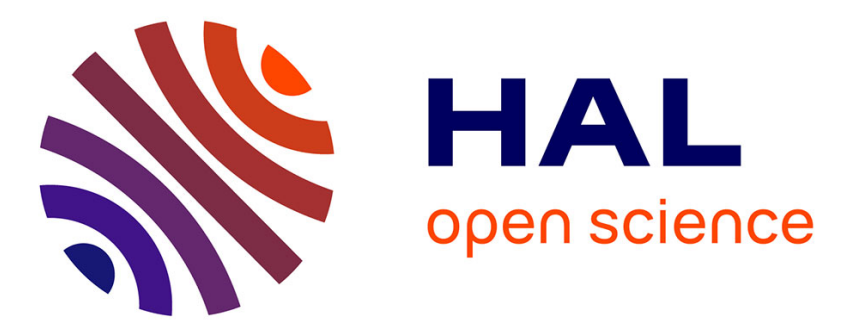

\title{
Avoiding non-contributive molecular results in cancer samples: proposal of a score-based approach for sample choice
}

Amélie Bourhis, Annabelle Remoué, Glen Le Flahec, Pascale Marcorelles, Arnaud Uguen

\section{To cite this version:}

Amélie Bourhis, Annabelle Remoué, Glen Le Flahec, Pascale Marcorelles, Arnaud Uguen. Avoiding non-contributive molecular results in cancer samples: proposal of a score-based approach for sample choice. Pathology, 2019, 51 (5), pp.524-528. 10.1016/j.pathol.2019.03.008 . hal-02195890

\section{HAL Id: hal-02195890 \\ https://hal.univ-brest.fr/hal-02195890}

Submitted on 25 Oct 2021

HAL is a multi-disciplinary open access archive for the deposit and dissemination of scientific research documents, whether they are published or not. The documents may come from teaching and research institutions in France or abroad, or from public or private research centers.
L'archive ouverte pluridisciplinaire HAL, est destinée au dépôt et à la diffusion de documents scientifiques de niveau recherche, publiés ou non, émanant des établissements d'enseignement et de recherche français ou étrangers, des laboratoires publics ou privés.

\section{(ㄷ)(1) $\$$}

Distributed under a Creative Commons Attribution - NonCommerciall 4.0 International 
Title: Avoiding non contributive molecular results in cancer samples: proposal of a score-based approach for sample choice.

Running head: Non contributive molecular tests in cancer samples

Authors: Amélie Bourhis ${ }^{1 *}$, Annabelle Remoué ${ }^{1 *}$, Glen Le Flahec ${ }^{1}$, Pascale Marcorelles ${ }^{1}$, Arnaud Uguen $^{1,2 \$}$

1 ; CHRU Brest, Department of Pathology, Brest, F-29220 France ;

2 ; Inserm U1053 BaRITOn, Bordeaux, F-33076 France

* indicates that the two authors ( $A B$ and $A R$ ) have contributed equally to this work.

Authors'e-mails : amelie.bourhis@chu-brest.fr; annabelle.remoue@chu-brest.fr; glen.leflahec@chubrest.fr; pascale.marcorelles@chu-brest.fr; arnaud.uguen@chu-brest.fr

Corresponding author $\left({ }^{(}\right)$:

Dr Arnaud Uguen; Department of Pathology, University Hospital Morvan, 2, avenue Foch 29609 Brest, France ; arnaud.uguen@chu-brest.fr; Tel + 332982233 49; Fax + 33298223334

Conflict of interest: none (for all authors).

The authors declare no source of support in this work. 


\section{Summary}

Mutational analyses have become crucial for therapeutic choices in patients with advanced lung cancer, colorectal cancer and melanoma. Short turnaround time in molecular analyses are necessary to match with the patient's therapeutic management. Non-contributive molecular analyses may increase the delay to reach a relevant mutational status. We attempted to identify samples criteria associated with non contributive molecular results to better anticipate them and select samples able to permit contributive analyses.

We compared several criteria as cancer type, sample type, organ of origin and percentage of tumor cells between samples with non-contributive or contributive EGFR, KRAS, NRAS and BRAF mutation analyses.

Among two sets of 3367 and 554 tumor samples analyses in 2015 to 2017 and 2018 respectively, $11.7 \%$ to $15.7 \%$ of sample analyses were non contributive for at least one oncogene. Lung cancer and melanoma cancer subtype (Odds Ratio $O R=7.2$ ), cytological $(\mathrm{OR}=1.8$ ) or bone samples $(O R=8.5)$ and a percentage of tumor cells $\leq 20 \%(O R=41.4)$ were significantly associated with non-contributive results. By combining these parameters in a scoring system, we were able to predict the contributive or non contributive result of a molecular analysis with a sensitivity and a specificity higher than $80 \%$ in a validation set of samples.

Predicting the contributive or non contributive result of a molecular analysis is feasible on the basis of simple samples' features. Combining these features could be used for better choosing samples to analyze in order to reduce the rate of non contributive molecular result and relatedtreatment delays and costs in patients with advanced cancers.

Keywords: cancer; molecular analysis failure; preanalytical; turnaround time; pathology. 


\section{Introduction}

In the last decades, a better understanding of the molecular bases of cancer initiation, progression and anti-tumor immunity response escape has lead to the development of new therapeutic strategies. Indeed, targeted treatments against oncogenic proteins and immunecheckpoint inhibitors have improved quality of life and treatment outcomes of cancer patients. Thus, assessment of predictive biomarkers is now crucial for relevant therapeutic choices in patients with advanced cancers.

Examples of predictive biomarkers include in colorectal cancer (CRC) mutations of KRAS and NRAS; in non-small-cell lung cancer (NSCLC) mutations of EGFR and KRAS and rearrangements of ALK and ROS1; in melanoma BRAF and NRAS mutations. ${ }^{1-3}$ Because of their requirements in terms of expensive equipments and skilled personnel, these mutational assays are often centralized in reference laboratories. The long interval of time between test prescription and result delivery may delay the treatment of patients with advanced cancers, some of them suffering of acute deterioration and needing rapid therapeutic decisions. The time of delivery of a relevant for therapeutic choice result may be increased when a first analysis leads to a non contributive result and, as a result, when a second analysis must be performed on another tumor sample. Non contributive results can be caused by several preanalytical concerns such as poor-cell samples, fixation delay or decalcification resulting in poor DNA quality. ${ }^{4,5}$ In this manner, in case of multiple tumor samples per patient, especially in patients with advanced cancers and multiple different primary and metastatic tumor samples available, the choice of one tumor sample or another for molecular analysis is worth in order to minimize the risk of non contributive results and of delayed therapeutic decision. 
As a part of our quality continuous improvement-based approach, we led a study searching for the most common features associated with non contributive molecular results in our daily practice. On the one hand, this study could led to future attempts to improve analytic processes in these "challenging" samples. In the other hand, it could permit also to prioritize less challenging tumor samples to get contributive molecular results as fast as possible for rapid treatment choices in patients with advanced NSCLC, CRC or melanomas.

\section{Materials and Methods}

\subsection{Workflow for molecular analyses in cancer samples}

We led a study about the molecular analyses performed in the Brest Molecular Genetics Platform of Cancer between $1^{\text {st }}$ January 2015 and $31^{\text {th }}$ August 2018. The Brest Molecular Genetics Platform of Cancer is located in the Brest University Hospital and performs the molecular tests for tumor samples of patients treated at the Brest University Hospital but also in other regional institutions from west Brittany. Samples are first sent to the Pathology department where unstained tissue sections dedicated to macrodissection, DNA extraction and Next Generation Sequencing (NGS) molecular analyses are produced and transmitted to the Molecular Genetics department where NGS analyses are performed. DNA extraction is performedusing the Maxwell 16 FFPE Plus LEV DNA purification kit (Promega) and NGS analyses are performed using a customized gene panel on lon PGM or Proton sequencers (Ion Torrent, Thermofisher; KRAS exons 2 to 4, reference sequence NM_033360.3; BRAF exon 15, reference sequence NM_004333.4; EGFR exons 18 to 21 reference sequence NM_005228.3, NRAS exons 2 to 4, reference sequence NM_002524.4). The limit of detection of the analytic process is given at $5 \%$ of mutated alleles with a minimal coverage of $400 \mathrm{X}$. Molecular genetics results, contributive or non contributive ones, are finally sent to the pathologists having selected the tumor sample for molecular analysis and to the clinicians assuming the treatment of patients. 


\subsection{Criteria}

We used the indicators applied in our Pathology laboratory to collect data about the following variables: the origin of the tumor samples (from "laboratory 1 " to "laboratory $4 "$ "), the nature of the samples analyzed (i.e. formalin fixed and paraffin embedded (FFPE) versus cytological samples), bone metastases or other organs, the content in tumor cells expressed in percentage of tumor cells among the total number of cells contained in the tumor area used for macrodissection and DNA extraction, the contributive or non contributive result of molecular analyses given by the Molecular Genetics department (reasons for non contributive results were not retrospectively available) and the delay between the date of sample reception in the Pathology Department and the final result sending to the clinicians. We focused on analyses requiring DNA extraction sent to the Molecular Genetics department i.e. EGFR and KRAS analyses in NSCLC, KRAS and NRAS analyses in CRC and BRAF and NRAS analyses in melanoma samples. Morphological tests performed in different pathology laboratories were not included in our study (i.e. immunohistochemistry and/or fluorescent in situ hybridization for $A L K$ and ROS1 testing in lung cancer). Genetics analyses were concluded as "contributive" for a sample when a molecular result was concluded by the geneticist for the two oncogenes for the corresponding tumor subtype. At the opposite, a "non contributive" result was referred to a failure of mutational analysis for one or the two oncogenes. As patients' data were fully anonymized and not taken into account in our study, formal approval of a local ethics committee was not required. The samples were registered in the tumor tissue collection CHRU Brest, $C P P n^{\circ} D C-$ $2008-214$

\subsection{Statistical analyses}


Chi-squared tests were used to compare the frequencies of non-contributive and contributive results according to the different qualitative criteria listed above. The mean duration from sample reception to molecular result and percentage of tumor cells within sample used for DNA extraction between samples with non-contributive and contributive results were compared using Mann-Whitney tests. Logistic regression and comparisons of areas under the receiver operating characteristic curves (AUC) were used searching for the parameter(s) able to predict the noncontributive result of a molecular analysis. Searching for a model able to predict the non contributive result of the analyses, a first round of analyses was led on the samples analyzed in 2015 to 2017 whereas the samples analyzed in 2018 were used as a validation set. Statistical analyses were performed using MedCalc Statistical Software version 13.2.2 (MedCalc Software bvba, Ostend, Belgium; http://www.medcalc.org; 2014). The level of significance was set at $p<0.05$.

\section{Results}

A first set of analyses were performed considering 3367 tumor samples with oncogenes mutational analyses performed between 1st January 2015 and 31th December 2017 (see Tables 1 to 3 for details). The four pathology laboratories outsourced different proportions of NSCLC, CRC and melanoma samples, as well as different proportions of FFPE versus cytological samples and bone versus other organs samples (Table 1). The proportions of FFPE versus cytological and bone versus other organs samples as well as the mean percentages of tumors cells also significantly varied across NSCLC, CRC and melanoma samples (Table 2).

Among the 3367 tumor samples, 393 (11.7\%) had a non-contributive molecular result for at least one oncogene (265 samples with non contributive results for the 2 oncogenes and 128 samples with a non contributive result for 1 oncogene). Using univariate analyses, the laboratory of origin, the type of cancer, the "FFPE versus cytological" criterion, the "bone versus other organ" criterion and 
the percentages of tumor cells were significantly different between samples with non-contributive molecular results and those with full contributive analyses (Table 3). Using logistic regression analyses, the laboratory of origin was not retained in the final model but the type of cancer (NSCLC versus CRC or melanoma), the "FFPE versus cytological" and "bone versus other organs" criteria as well as the percentage of tumor cells ( $\leq 20 \%$ versus $>20 \%$, cut-off established on the basis of an AUC analysis, data not shown) remained independent factors significantly associated with a noncontributive molecular result (Table 3).

Given the Odd-Ratios obtained for the different factors associated with a non-contributive molecular result, we attempted to establish a scoring system based on the samples' features able to predict the contributive or non-contributive result of a molecular analysis. The score combining the percentage of tumor cells $(\leq 20 \%$ tumor cells versus $>20 \%)$, the type of sample (bone/cytological/other FFPE sample; no bone sample was of cytological type) and the type of cancer (NSCLC/melanoma/CRC) reached the highest performances (i.e. significantly superior AUC, see Score B in Table 4) and permitted to differentiate between non-contributive and contributive analyses with a sensitivity of $59 \%$ ([54;63.9] 95\% C.I.) and a specificity of $90.9 \%$ ([89.8;91.9] 95\% C.I.) using a cut-off value of $>2$ (see Figure 1).

We have subsequently validated our scoring system on a new set of 554 samples analyzed between 1st January 2018 and 31th August 2018 (15.7\% of non contributive molecular analyses, see Table 5 for details). In this new set of samples, our scoring system reached a sensitivity of $88.5 \%$ ([79.9;94.3] 95\% C.I.) and a specificity of $82.4 \%$ ([78.7;85.8] 95\% C.I.) to predict the non contributive or contributive result of a molecular analysis (see Figure 1). 


\section{Discussion}

A rapid delivery of a molecular result relevant for treatment choices is crucial for optimal therapeutic choices and management in patients with advanced cancers for which targeted therapies are approved, e.g. NSCLC, CRC and melanoma. A first round of non-contributive analyses on a first tumor sample may increase the delay to obtain a contributive result by requiring new analyses on a second sample. In our study, times for results delivery were almost equal (2018 period) or even slightly significantly longer (2015-2017 period) for the samples with non contributive results when compared with samples with fully contributive analyses (about 2 weeks, see Tables 3 and 5). As a result, a first non-contributive result will only permit to get an information usable for treatment choices in about 4 weeks for $10-15 \%$ of the patients analyzed in our institution for who molecular analyses have to be repeated. For this reason, it could be interesting to be able to predict the contributive or non-contributive result of a molecular analysis prior to its processing on the basis of simple features of the tumor samples. This could help to choose between different samples (when available for a same patient) to maximize the chance to get a mutational status from the first analysis.

A vast number of factors may affect the molecular analyses of tumor samples, e.g. preanalytical factors as ischemia and fixation durations, tissue storage conditions, decalcification, dehydratation and paraffin embedding processes but also some proper features of the sample as its content in terms of percentage of tumor cells, its size, the presence of polymerase chain reaction inhibitors as melanin for example. ${ }^{4-7}$ The optimal conditions to get the most efficient molecular analyses are the subject of dedicated-guidelines but, in daily practice, it is very difficult in a qualityprocess to efficiently monitor as many indicators as there are numerous potential sources of molecular analyses failure. ${ }^{4,5,7-10}$ In this manner, on the basis of simple criteria assessable at the time of sample choice by a pathologist, we have attempted to identify a strategy to minimize the risk of 
choosing a sample with non contributive molecular result. Tumor types, sample type (i.e. FFPE versus cytological sample), tissue type (i.e. bone sample or not) and the percentage of tumor cells are some parameters easy to obtain and have permitted us to build a score able to predict the contributive or non-contributive result of a molecular analysis with a sensitivity and a specificity higher than $80 \%$ in our validation set of samples.

Nevertheless, our study has several limitations. First, several other easy-to-obtain parameters had not been collected at the time of tumor sample analysis and were not retrospectively assessable, e.g. the size of sample, its content in melanin pigment, sample type with FFPE and cytological categories, the precise age of samples. Beside the term "bone metastasis" among other organs of origin, the existence of a preanalytical step of decalcification was also not mentioned. Indeed, despite been frequently performed in bone samples and classically involved in the failure of molecular analyses, the decalcification process may be not necessary if the tumor cells have destroyed enough the osseous calcified tissue. Albeit we cannot retrospectively attest which samples had undergone a decalcification process, supporting this hypothesis that the richest in tumor cell samples have less undergone a decalcification-related DNA alteration, we can note that, in the bone metastases samples of our study, the percentage of tumor cells was significantly higher in samples with contributive molecular analyses than in those with non contributive results (means of $70 \%[62.8 ; 77.3] 95 \%$ C.I. and $40 \%[30.3 ; 49.7]$ respectively, $p<0.0001)$. It could be interesting in the future to integrate some additional parameters to further investigate for their impact on the results of molecular analyses. Secondly, under the term "non contributive", we have chosen not to perform separate analyses between samples with 0 and 1 contributive results for the 2 oncogenes analyzed per tumor sample. We have made this choice because an incomplete mutational status may lead to inadequate treatment choices. Nevertheless, it could be also interesting to consider the features associated with the failure of one particular oncogene analysis or of the global molecular analysis. 
Thirdly, significant differences appeared from one pathology laboratory providing tumor samples to the molecular genetics platform to another; we hypothesize that some differences could also exist from one molecular genetics platform to another with different pathology laboratories and different molecular analyses protocols and methods. In this manner, our results may not be directly applicable in another molecular genetics platform and would merit a validation in different institutions. Finally, we only focused on one method of mutational analyses in the field of NSCLC, CRC and melanoma samples highlighting a difference between these different cancer types and we hypothesize reasonably that our conclusions are not strictly applicable on the one hand, to other cancer subtypes, and, in the other hand, to molecular morphological analyses as in situ hybridization based ones. Additional studies will be necessary to assess the features associated with contributive and non contributive analyses about other tumors subtypes and other molecular methods.

\section{Conclusion}

To conclude, beyond its limitations, this study will permit us to progress in the quality of the preanalytical management and choice of a tumor sample in patients with advanced cancer requiring predictive mutational analyses. The strategy proposed in this study trying to minimize the risk of first analysis non-contributive results, based on easy-to-obtain features of tumor samples, could help each laboratory to perform its own quality study with its own indicators to improve its rate of firstround contributive molecular analyses and, as a consequence, to reduce the delay between the prescription of a molecular analysis and the final delivery of an information relevant for treatment choices in patients with advanced cancers. 
Acknowledgements: The authors would like to acknowledge the molecular pathology staff of the Department of Pathology of Brest University Hospital, the pathologists from West Brittany and the geneticists of Brest University Hospital for their daily collaboration in molecular testing in cancer samples.

Author contributions: All the authors have accepted responsibility for the entire content of this submitted manuscript and approved submission.

Research funding: None declared.

Employment or leadership: None declared.

Honorarium: None declared.

Competing interests: The authors have declared no conflict of interest in this work. 


\section{References}

1. Benson AB 3rd, Venook AP, Cederquist L, et al. Colon Cancer, Version 1.2017, NCCN Clinical Practice Guidelines in Oncology. J Nat/ Compr Canc Netw. 2017;15:370-98

2. Lindeman NI, Cagle PT, Aisner DL, et al. Updated Molecular Testing Guideline for the Selection of Lung Cancer Patients for Treatment With Targeted Tyrosine Kinase Inhibitors: Guideline From the College of American Pathologists, the International Association for the Study of Lung Cancer, and the Association for Molecular Pathology. Arch Pathol Lab Med. 2018;142:321-46.

3. Coit DG, Thompson JA, Algazi A, et al. NCCN Guidelines Insights: Melanoma, Version 3.2016. J Natl Compr Canc Netw. 2016;14:945-58.

4. Bass BP, Engel KB, Greytak SR, Moore HM. A review of preanalytical factors affecting molecular, protein, and morphological analysis of formalin-fixed, paraffin-embedded (FFPE) tissue: how well do you know your FFPE specimen? Arch Path Lab Med. 2014;138:1520-30.

5. True LD. Methodological requirements for valid tissue-based biomarker studies that can be used in clinical practice. Virchows Arch. 2014;464:257-63.

6. Eckhart L, Bach J, Ban J, Tschachler E. Melanin binds reversibly to thermostable DNA polymerase and inhibits its activity. Biochem Biophys Res Commun. 2000;271:726-30.

7. Susman S, Berindan-Neagoe I, Petrushev B, et al. The role of the pathology department in the preanalytical phase of molecular analyses. Cancer Manag Res. 2018;10:745-53.

8. Bellevicine $\mathrm{C}$, Malapelle $\mathrm{U}$, Vigliar $\mathrm{E}$, et al. How to prepare cytological samples for molecular testing. J Clin Pathol. 2017;70:819-26.

9. Dietel $M$, Budendorf L, Dingemans AM, et al. Diagnostic procedures for non-small-cell lung cancer (NSCLC): recommendations of the European Expert Group. Thorax. 2016;71:177-84.

10. Wong NA, Gonzalez D, Salto-Tellez M, et al. RAS testing of colorectal carcinoma - a guidance document for the Association of Clinical Pathologists Molecular Pathology and Diagnostics Group. J Clin Pathol. 2014;67:751-7. 


\section{Figures legends}

Figure 1. Receiver operating characteristic (ROC) curves ( $A$ and $B$ ) and histograms summarizing the scores among samples with contributive ( $C$ and $D$ ) or non-contributive ( $E$ and $F$ ) molecular analyses (final score data; A, C and E correspond to the 2015-2017 sample set and B, D and F correspond to the 2018 tumor set; the vertical black bar in C to F illustrates the cut-off value between a score predicting a contributive analysis $\leq 2$ or a non-contributive analysis $>2$ ). 


\section{Tables}

Table 1. Comparison of the types of samples and cancers across the four pathology laboratories (2015-2017 samples set)

NSCLC: non-small-cell lung cancer; CRC: colorectal cancer; FFPE: formalin-fixed paraffin embedded.

\begin{tabular}{|c|c|c|c|c|c|c|c|}
\hline & \multicolumn{3}{|c|}{ Type of cancer } & \multicolumn{2}{c|}{ Type of sample } & \multicolumn{2}{c|}{ Origin of sample } \\
\hline Laboratory & NSCLC & CRC & Melanoma & FFPE & Cytological & Bone metastasis & Others \\
\hline \multirow{2}{*}{1} & 773 & 252 & 158 & 1012 & 171 & 47 & 1136 \\
& $(65.3 \%)$ & $(21.3 \%)$ & $(13.4 \%)$ & $(85.5 \%)$ & $(14.5 \%)$ & $(4 \%)$ & $(96 \%)$ \\
\hline \multirow{2}{*}{2} & 2 & 325 & 7 & 334 & 0 & 1 & 333 \\
& $(0.6 \%)$ & $(97.3 \%)$ & $(2.1 \%)$ & $(100 \%)$ & $(0 \%)$ & $(0.3 \%)$ & $(99.7 \%)$ \\
\hline \multirow{2}{*}{3} & 422 & 333 & 94 & 836 & 13 & 7 & 842 \\
& $(49.7 \%)$ & $(39.2 \%)$ & $(11.1 \%)$ & $(98.5 \%)$ & $(1.5 \%)$ & $(0.8 \%)$ & $(99.2 \%)$ \\
\hline \multirow{2}{*}{4} & 571 & 352 & 78 & 990 & 11 & 3 & 998 \\
& $(57 \%)$ & $(35.2 \%)$ & $(7.8 \%)$ & $(98.9 \%)$ & $(1.1 \%)$ & $(0.3 \%)$ & $(99.7 \%)$ \\
\hline
\end{tabular}


Table 2. Comparison of the types of samples and percentages of tumor cells across the different cancer types (2015-2017 samples set)

NSCLC: non-small-cell lung cancer; CRC: colorectal cancer; FFPE: formalin-fixed paraffin embedded.

\begin{tabular}{|c|c|c|c|c|c|}
\hline \multirow[b]{2}{*}{ Type of cancer } & \multicolumn{2}{|c|}{ Type of sample } & \multicolumn{2}{|c|}{ Origin of sample } & \multirow{2}{*}{$\begin{array}{l}\text { Percentage of } \\
\text { tumor cells } \\
\text { (mean and } \\
\text { 95\%C.I.); } \\
\text { range }\end{array}$} \\
\hline & FFPE & Cytological & Bone metastasis & Others & \\
\hline NSCLC & $\begin{array}{c}1575 \\
(89.1 \%)\end{array}$ & $\begin{array}{c}193 \\
(10.9 \%)\end{array}$ & $\begin{array}{c}45 \\
(2.5 \%)\end{array}$ & $\begin{array}{c}1723 \\
(97.5 \%)\end{array}$ & $\begin{array}{c}53.9 \% \\
{[52.7 ; 55.2] ;} \\
(1-90)\end{array}$ \\
\hline CRC & $\begin{array}{c}1262 \\
(100 \%)\end{array}$ & $\begin{array}{c}0 \\
(0 \%)\end{array}$ & $\begin{array}{c}8 \\
(0.6 \%)\end{array}$ & $\begin{array}{c}1254 \\
(99.4 \%)\end{array}$ & $\begin{array}{c}51.4 \% \\
{[50.2 ; 52.7] ;} \\
(5-85)\end{array}$ \\
\hline Melanoma & $\begin{array}{c}335 \\
(99.4 \%)\end{array}$ & $\begin{array}{c}2 \\
(0.6 \%)\end{array}$ & $\begin{array}{c}5 \\
(1.5 \%)\end{array}$ & $\begin{array}{c}332 \\
(98.5 \%)\end{array}$ & $\begin{array}{c}70.4 \% \\
{[68 ; 72.8] ;} \\
(5-100)\end{array}$ \\
\hline
\end{tabular}


Table 3. Summary of the factors associated with contributive and not contributive molecular analyses (2015-2017 samples set)

OR: Odds-Ratio; C.I.: confidence interval; NSCLC: non-small-cell lung cancer; CRC: colorectal cancer; FFPE: formalin-fixed paraffin embedded; *: indicates p-values $<0.05$, " : indicates NSCLC vs not NSCLC; \#\#:: indicates $\leq 20 \%$ tumor cells versus $>20 \%$

\begin{tabular}{|c|c|c|c|c|c|}
\hline & & $\begin{array}{l}\text { Non contributive } \\
\text { analyses for } 1 \text { or } \\
2 \text { gene(s) }\end{array}$ & $\begin{array}{l}\text { Contributive } \\
\text { analyses for } 2 \\
\text { genes }\end{array}$ & $\begin{array}{c}\text { Univariate } \\
\text { analyses } \\
p \text {-values }\end{array}$ & $\begin{array}{c}\text { Logistic } \\
\text { Regression } \\
\text { OR [95\% C.I] }\end{array}$ \\
\hline & Total & $N(\%)$ & $N(\%)$ & & \\
\hline Total & $3367(100 \%)$ & 393 (11.7\%) & $2974(88.3 \%)$ & & \\
\hline \multicolumn{6}{|l|}{ Laboratory } \\
\hline 1 & $1183(35,1 \%)$ & $181(15,3 \%)$ & $1002(84,7 \%)$ & \multirow{4}{*}{$\mathrm{p}<0.0001^{*}$} & \multirow{4}{*}{$\begin{array}{l}\text { Not included } \\
\text { in the final } \\
\text { model }\end{array}$} \\
\hline 2 & 334 (9.9\%) & $15(4.5 \%)$ & 319 (95.5\%) & & \\
\hline 3 & 849 (25.2\%) & 99 (11.7\%) & $750(88,3 \%)$ & & \\
\hline 4 & $1001(29,7 \%)$ & $98(9.8 \%)$ & 903 (90.2\%) & & \\
\hline \multicolumn{6}{|l|}{ Type of cancer } \\
\hline NSCLC & $1768(52.5 \%)$ & 327 (18.5\%) & $1441(81.5 \%)$ & \multirow{3}{*}{$p<0.0001^{*}$} & \multirow{3}{*}{$\begin{array}{c}\mathrm{OR}=7.2^{\#} \\
{[5.1 ; 10.3]}\end{array}$} \\
\hline CRC & $1262(37.5 \%)$ & $32(2.5 \%)$ & $1230(97.5 \%)$ & & \\
\hline Melanoma & $337(10 \%)$ & $34(10.1 \%)$ & 303 (89.9\%) & & \\
\hline \multicolumn{6}{|l|}{ Type of sample } \\
\hline FFPE & 3171 (94.2\%) & 341 (10.8\%) & $2830(89.2 \%)$ & \multirow{2}{*}{$\mathrm{p}<0.0001^{*}$} & $\mathrm{OR}=1.8$ \\
\hline Cytological & $195(5.8 \%)$ & $52(26.7 \%)$ & $143(73.3 \%)$ & & {$[1.1 ; 2.9]$} \\
\hline \multicolumn{6}{|l|}{ Origin of sample } \\
\hline Bone metastasis & $58(1.7 \%)$ & 27 (46.6\%) & $31(53.4 \%)$ & \multirow{2}{*}{$\mathrm{p}<0.0001^{*}$} & \multirow{2}{*}{$\begin{array}{c}\mathrm{OR}=8.5 \\
{[4.7 ; 15.3]}\end{array}$} \\
\hline Others & 3309 (98.3\%) & 366 (11.1\%) & $2943(88.9 \%)$ & & \\
\hline & $\begin{array}{c}\text { Mean } \\
{[95 \% \text { C.I] }}\end{array}$ & $\begin{array}{c}\text { Mean } \\
{[95 \% \text { C.I] }}\end{array}$ & $\begin{array}{c}\text { Mean } \\
{[95 \% \text { C.I] }}\end{array}$ & & \\
\hline $\begin{array}{c}\text { Percentage of } \\
\text { tumor cells }\end{array}$ & $\begin{array}{c}54.7 \% \\
{[53.8 ; 55.5]}\end{array}$ & $\begin{array}{c}24.4 \% \\
{[22 ; 26.7]}\end{array}$ & $\begin{array}{c}58.6 \% \\
{[57.8 ; 59.4]}\end{array}$ & $\mathrm{p}<0.0001^{*}$ & $\begin{array}{c}\text { OR=41.4"\# } \\
{[29.2 ; 58.8]}\end{array}$ \\
\hline $\begin{array}{l}\text { Duration until } \\
\text { result delivery }\end{array}$ & $\begin{array}{c}16 \text { days } \\
\{15.8 ; 16.3]\end{array}$ & $\begin{array}{c}17.3 \text { days } \\
{[16.3 ; 18.3]}\end{array}$ & $\begin{array}{c}15.9 \text { days } \\
{[15.6 ; 16.2]}\end{array}$ & $p=0.0027^{*}$ & \\
\hline
\end{tabular}


Table 4. Comparison of two scoring systems to predict contributive or non contributive molecular analyses (2015-2017 samples set)

AUC: area under the receiver operating characteristic curve; NSCLC: non-small-cell lung cancer; CRC: colorectal cancer; FFPE: formalin-fixed paraffin embedded; *: indicates p-values $<0.05$.

\begin{tabular}{|c|c|c|c|c|c|c|}
\hline & $\begin{array}{c}\text { Percentage } \\
\text { of tumor } \\
\text { cells }\end{array}$ & $\begin{array}{c}\text { Bone, } \\
\text { cytological, } \\
\text { other FFPE } \\
\text { sample }\end{array}$ & $\begin{array}{l}\text { Type of } \\
\text { cancer }\end{array}$ & $\begin{array}{l}\text { Total } \\
\text { score }\end{array}$ & $A U C$ & $p$-value \\
\hline Score A & \multirow{2}{*}{$\begin{array}{l}\leq 20 \%: 4 \\
>20 \%: 0\end{array}$} & \multirow{2}{*}{$\begin{array}{c}\text { Bone : } 3 \\
\text { Cytological: } 1 \\
\text { Other FFPE: } 0\end{array}$} & $\begin{array}{l}\text { NSCLC: } 2 \\
\text { Other: } 0\end{array}$ & \multirow[b]{2}{*}{$0-9$} & 0.815 & \multirow[b]{2}{*}{$p=0.0004 *$} \\
\hline Score B & & & $\begin{array}{c}\text { NSCLC: } 2 \\
\text { Melanoma: } 1 \\
\text { CRC: } 0\end{array}$ & & 0.823 & \\
\hline
\end{tabular}


Table 5. Summary of the factors associated with contributive and not contributive molecular analyses in the 2018 samples validation set.

C.I.: confidence interval; NSCLC: non-small-cell lung cancer; CRC: colorectal cancer; FFPE: formalinfixed paraffin embedded; *: indicates $p$-values $<0.05$

\begin{tabular}{|c|c|c|c|c|}
\hline & & $\begin{array}{c}\text { Non contributive } \\
\text { analyses for } 1 \text { or } 2 \\
\text { gene(s) }\end{array}$ & $\begin{array}{l}\text { Contributive analyses } \\
\text { for } 2 \text { genes }\end{array}$ & $\begin{array}{c}\text { Univariate } \\
\text { analyses } \\
\text { p-values }\end{array}$ \\
\hline & Total & $N(\%)$ & $N(\%)$ & \\
\hline Total & 554 (100\%) & 87 (15.7\%) & 467 (84.3\%) & \\
\hline \multicolumn{5}{|l|}{ Type of cancer } \\
\hline NSCLC & 319 (57.6\%) & $68(21.3 \%)$ & 251 (78.6\%) & \multirow{3}{*}{$p<0.0001^{*}$} \\
\hline CRC & $162(29.2 \%)$ & $2(1.2 \%)$ & $160(98.8 \%)$ & \\
\hline Melanoma & 73 (13.2\%) & $17(23.3 \%)$ & $56(76.7 \%)$ & \\
\hline \multicolumn{5}{|l|}{ Type of sample } \\
\hline FFPE & 494 (89.2\%) & $77(15.6 \%)$ & 417 (84.4\%) & \multirow{2}{*}{$\mathrm{p}=0.8283$} \\
\hline Cytological & $60(10.8 \%)$ & $10(16.7 \%)$ & $50(83.3 \%)$ & \\
\hline \multicolumn{5}{|l|}{ Origin of sample } \\
\hline Bone metastasis & $9(1.6 \%)$ & $6(66.7 \%)$ & $3(33.3 \%)$ & \multirow{2}{*}{$p<0.0001^{*}$} \\
\hline \multirow[t]{2}{*}{ Others } & 545 (98.4\%) & $81(14.8 \%)$ & $464(85 ; 1 \%)$ & \\
\hline & $\begin{array}{c}\text { Mean } \\
{[95 \% \text { C.I] }}\end{array}$ & $\begin{array}{c}\text { Mean } \\
{[95 \% \text { C.I] }}\end{array}$ & $\begin{array}{c}\text { Mean } \\
{[95 \% \text { C.I] }}\end{array}$ & \\
\hline $\begin{array}{c}\text { Percentage of tumor } \\
\text { cells }\end{array}$ & $\begin{array}{c}50.4 \% \\
{[48.2 ; 52.6]} \\
\end{array}$ & $\begin{array}{c}20.3 \% \\
{[16.6 ; 24.1]} \\
\end{array}$ & $\begin{array}{c}56.3 \% \\
{[54.2 ; 58.4]}\end{array}$ & $p<0.001^{*}$ \\
\hline $\begin{array}{c}\text { Duration until result } \\
\text { delivery }\end{array}$ & $\begin{array}{c}17.3 \text { days } \\
\{16.6 ; 18.1]\end{array}$ & $\begin{array}{c}16.7 \text { days } \\
{[15.7 ; 17.7]}\end{array}$ & $\begin{array}{l}17.5 \text { days } \\
{[16.6 ; 18.3]}\end{array}$ & $p=0.8047$ \\
\hline
\end{tabular}


A

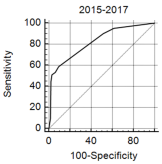

C

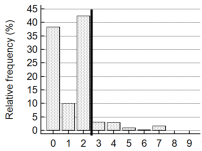

E

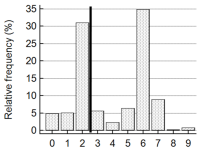

B

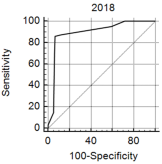

D

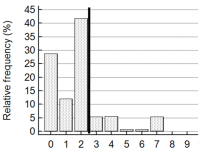

F

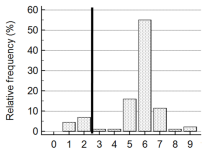

